Journal of Southeast Asian

Volume 15

Issue 2 Voices from the Field: Centering

Southeast Asian Americans through Policy,

Article 5

Practice, and Activism

2020

\title{
Journeying "Home": Negotiating Belonging as Vietnamese American Việt Kiều
}

Mary Yee

University of Pennsylvania, miaoshao.yee@gmail.com

Follow this and additional works at: https://docs.lib.purdue.edu/jsaaea

Part of the Bilingual, Multilingual, and Multicultural Education Commons

\section{Recommended Citation}

Yee, Mary (2020) "Journeying "Home": Negotiating Belonging as Vietnamese American Việt Kiều," Journal of Southeast Asian American Education and Advancement. Vol. 15 : Iss. 2, Article 5.

DOI: $10.7771 / 2153-8999.1207$

Available at: https://docs.lib.purdue.edu/jsaaea/vol15/iss2/5

This document has been made available through Purdue e-Pubs, a service of the Purdue University Libraries.

Please contact epubs@purdue.edu for additional information.

This is an Open Access journal. This means that it uses a funding model that does not charge readers or their institutions for access. Readers may freely read, download, copy, distribute, print, search, or link to the full texts of articles. This journal is covered under the CC BY-NC-ND license. 


\section{Journeying "Home": Negotiating Belonging as Vietnamese American Việt Kiều}

\section{Cover Page Footnote}

I am deeply grateful to BT, TK, and VT, the amazing student leaders of the Asian Student Association of Philadelphia (ASAP), for sharing their life stories and supporting my work. 


\title{
JSAAEA Journal of Southeast Asian American
Education and Advancement
}

Vol. 15 Iss. 2 Special Issue (2020) www.JSAAEA.org

\section{Journeying "Home": Negotiating Belonging as Vietnamese American Việt Kiều}

\author{
Mary Yee \\ University of Pennsylvania
}

\begin{abstract}
For Southeast Asian young people who left as adolescents from their home countries, their connections to those places are often fraught with ambiguity. As for almost all first-generation immigrant youth, issues of belonging in America have touched multiple aspects of their lives, including issues of identity. Not belonging is the diasporic experience of the immigrant (Christou, 2011; Skrbis, 2008). This qualitative study examined the lived experience of three Vietnamese American young people returning home as Việt Kiều, or diasporic Vietnamese. For these emerging adults, it was an important developmental task to figure out one's place in the world: one's belief systems, group allegiances, and future life directions (Arnett, 2015). Returning to Vietnam on their own, reconnecting to relatives, and revisiting neighborhoods, homes, and villages where they grew up was indeed an important part of this task. Where was home and where did they, in fact, belong? Significantly, their recounting of their homecomings engendered epiphanies about their own emotional landscapes and social locations, both in the United States and in Vietnam. Exploring the interrelated emotional and physical journeys of young people has the potential of shedding light on issues of self-care and socio-emotional well-being in immigrant families and communities.
\end{abstract}

Keywords: First-generation immigrant youth, Vietnamese, Belonging

\section{Introduction}

While trying to "fit in" or "belong" is part of everyone's developmental journey, it is more poignant for those who are marginalized or racialized and live in daily circumstances of inequity and dispossession. For Southeast Asian young people who left as adolescents from their home countries, their intersectional identities and connections to both the United States and the home country places are often fraught with issues of belonging, ambiguity and continual negotiation. This qualitative study examined the lived experience of three Viet emerging adults returning to Vietnam for the first time since they migrated during their adolescence to the United States in the

\footnotetext{
@)

SDRERIIGHISRESEREEDReaders are free to copy, display, and distribute this article, as long as the work is attributed to the author(s) and the Journal of Southeast Asian American Education \& Advancement, it is distributed for non-commercial purposes only, and no alteration or transformation is made in the work. More details of this Creative Commons license are available at http://creativecommons.org/licenses/by-nc-nd/3.0/. All other uses must be approved by the author(s) or JSAAEA. Journal of Southeast Asian American Education \& Advancement, Vol. 15. Iss. 2. (2020) ISSN: 2153-8999
} 
2000s. I examined how their notions of "home" and sense of belonging were affected by their identity as Việt Kiều, their familial connections with relatives abroad, their intersectional identities at the time, and by memories of their former lives in Vietnam.

\section{Background and Context}

For almost all children of immigrant parents, issues of belonging in America have touched multiple aspects of their lives, not the least of which are issues of identity. The trope of living in the hyphen - although actually no longer used to signify some kind of ethnic-American — still harbors a certain truth about being neither fully one nor another kind of cultural citizen - that is, not really belonging here nor there (Thai, 1999).

\section{Not Belonging as Immigrant Students}

The three Viet young people-TK and VT, two males, and BT, a female-were student leaders at an urban comprehensive high school, who mounted a successful campaign against school violence and racial harassment following a brutal attack on Chinese and Vietnamese immigrant students. In their mid to late teens, they experienced the stress and social anxieties associated with migrating to a country with a vastly different culture and language. The message that they did not belong was everywhere present-from their separation from mainstream students by virtue of their English Language Learner (ELL) status to the physical and psychological threats at school and in their neighborhood. Their struggle against interracial student-on-student violence, which was exacerbated by the deliberate neglect of the school district, was an expression of resistance to not belonging and believing in the right to belong. In fact, by forming a high school student organization, which aimed to advocate for and organize Asian immigrant students across the district, the young leaders and their allies made a space where first-generation low-income students (FGLI) could feel they belonged. The student leaders were able to weather much of this alienation by virtue of their critical consciousness and close relationships with their mentors from the grassroots community organizations that had supported them during the high school struggle. They found allied community spaces where they were accepted and belonged. Nonetheless, the emotional labor in negotiating "belonging" was considerable and at times even debilitating as youth attended college in predominantly White middle-class settings and also endured family conflict.

During and after college, the three young people all returned to visit Vietnam for the first time since leaving in their early teens. In reviewing the literature, I found studies of the return experiences of the first and second waves (pre- and post 1975-80s) of adult Vietnamese immigrants, but not of the later migration that followed a decade or more later as a result of family reunification provisions in U.S. immigration law, especially not of first generation young people. As Vietnamese Americans journeying "home," the three were confronting the issue of transnational belonging. Their identities as Việt Kiều, (the term is explained below) located them again in a precarious state between belonging and not belonging, but now in their home country.

\section{A Việt Kiều Identity}

The term Việt Kiều means literally overseas Vietnamese, or those in the diaspora living abroad from the home country. Some understanding of the connotations of the term is important in 
understanding how Việt Kiều are perceived and received by their friends and relatives who remained in Vietnam. Việt Kiều has gone through various phases of alternately being a derogatory or pejorative term to one indicating favored status (Hobson, n.d.; Koh, 2015; Long, 2004). Depending on nation building goals of the Hanoi government, the attitude vis-à-vis ethnic Vietnamese living abroad varied from being seen as potential anti-Communist saboteurs to sources of technical and professional skills, family remittances, or investment capital. (Long, 2004, pp. 6670; Vo, 2009, p. 3). Since Resolution 36, a landmark law regarding Việt Kiều rights, passed in 2004, Việt Kiều have certain privileges, including dual citizenship, incentives to buy property and invest in businesses, and exemption from visas (Koh, 2015, p. 185). In official language from 2010, state policies aimed to defend Việt Kiều's "legitimate rights and benefits both in the country and in their resident countries so that they feel that Vietnam is truly their home and their guardian" (Koh, ibid. citing Bao Moi, 2010).

Upon rereading the data from the original multi-case study, I found an analysis pertaining to the journeying "home" experience lacking. Feeling its importance as a dimension in their lives and intersectional transnational identities, I arrived at these research questions:

1. How did these young people experience their return to a land they had not seen since childhood?

2. How did they see "home" or "belonging" in relation to the United States or Vietnam?

\section{Methodology}

The data for this paper derives from research for a larger multi-case study of Asian immigrant youth activists (Yee, 2018). The qualitative study relied on data from interviews, focus groups, life texts, and review of archival documents from 2012-2017. Typically, transcripts or other text were coded and organized by themes related to the original research question related to the impact of political activism on the trajectories of the young people. However, embracing an emic approach based in grounded theory, I found that other topics emerged from the data, including the crosscutting issue of "belonging" or "not belonging" as the young people traversed various landscapes and settings. For example, on one hand, the young people encountered affirmation and support from family, community advocates, and allies during their struggle against school violence; on the other hand, they faced racism, xenophobia, academic elitism, or homophobia in their educational, familial, and social settings in the United States. In Vietnam, the young people faced a different kind of belonging/not belonging as an artifact of their intersectional identities as Vietnamese American Việt Kiều, not to mention their other subjectivities as college educated young adults or as consanguineal relatives.

\section{Theoretical Frameworks}

Asking "where do I belong" may be prompted by feeling that there are a range of spaces, places, locales and identities that we feel we do not, and cannot, belong to ... Belonging has a number of dimensions; belonging is about experiences of being part of the social fabric and should not be thought of in exclusively ethnic terms (Anthias, 2006, p. 21). 
Not belonging is the diasporic experience of the immigrant (Christou, 2011; Skrbis, 2008). Having lived most of their young lives away, the young people experienced their journeys "home" during or after college as significant emotional turning points. For emerging adults, as these young people were, it was an important developmental task to figure out one's belief systems, group allegiances, and future life directions (Arnett, 2015). Belonging relates to identity work that is done during adolescence and emerging adulthood. It is a turbulent time for young people especially so for young people who are first generation immigrants for whom the first language is other than English (Arnett, 2015; Suarez-Orozco, 2008). Returning to Vietnam on their own, reconnecting to relatives, and revisiting neighborhoods, homes, and villages where they grew up was indeed an important part of this task of figuring out whether they belonged there anymore, and, in fact, where they did belong.

Discussions of belonging and home are being addressed interdisciplinarily in the areas of cultural studies, feminist and gender studies, childhood/youth studies, and migration studies. Yuval-David proposed an analytical framework for discussing belonging. This framework is composed of three levels: a) social locations; b) individual identifications and emotional attachments; c) ethical and political value systems used to evaluate or validate belongings (2006, p. 199). Importantly she said that "constructions of belonging, however, cannot and should not be seen as merely cognitive stories. They reflect emotional investments and desire for attachments" (p. 202). Quoting Probyn, she added "individuals and groups are caught within wanting to belong, wanting to become, a process that is fueled by yearning rather than positing of identity as a stable value" (p. 202). Bell attributed a performative dimension to constructions of belonging, emphasizing specific repetitive practices related to particular social and cultural spaces connecting individual and collective behaviors (Bell, 1999).

In addition to the emotional or affective dimension of belonging, Yuval-Davis (2006) talks about the politics of belonging, which determines boundaries for in-groups versus out-groups. The concepts of citizenship, rights and responsibilities, and status and entitlement pertain to which requisites nation states mandate to belong. Nunn (2017), citing Probyn (1996) and Fortier (2000), conceptualized belonging in this way: "Different belongings may be experienced as different degrees of intensity and desire and commitment and diversely embodied, performed and signified (2017, p. 218). In summary, these theorists have led us to consider that social location, intersectional identities, value systems, performativity and emotional attachments pertain to notions of belonging.

While a substantial body of research exists around the lived experiences of secondgeneration students, there is a paucity of research about the lives of first-generation immigrant youth (Suárez-Orozco, Suárez-Orozco, \& Todorova, 2008). Although there has been some investigation into the transnational connections of second-generation immigrant young people to their mother countries (Somerville, 2008), there is less research on the transnational experiences of first-generation immigrant young people returning to their home countries. (Ní Laoire, CarpenaMéndez, Tyrrell, \& White, 2010).

I regard the questions of "where is home?" and "belonging" as inextricably linked to the young people's transnational and intersectional identities and dependent on social, locational, and temporal contexts (Anthias, 2009). Moreover, adopting Anthias' translocational approach allows us to treats lives as located across multiple but also fractured and inter-related social spaces. Narratives and strategies of identity and belonging are relationally produced (in terms of both commitment and struggle). They are situational, temporal and subject to different meanings and inflections. 


\section{Returning to Vietnam for the First Time}

As Anthias (2009) points out, for those who are embedded transnationally, there are two sets of social relations, arrangements and expectations (e.g., around gender, sexuality, and behavioral norms-particularly for migrant women and younger migrants) that impact upon their lives. In the following discussions, we see how these are reflected often in the perspectives of, on one hand, the Việt Kiều, once-native-now-overseas visitor, and, on the other hand, those who have lived long term in the home country.

\section{Trying Not to be Different, Wanting to Belong}

Calling each other "anh" (older brother) and "em" (a younger person) respectively, BT and TK had a close relationship and found in each other family members they did not have-an older brother and a younger sister. Thai identified this "friends as family" phenomenon in discussing Viet ethnic identity (1999, p. 72). The winter after TK graduated from college and during BT's winter break, they traveled to Vietnam with a mutual friend, also a FGLI Viet student. Before leaving, the three set their expectations for the trip.

TK, BT, and their friend agreed that they would try to blend in with the native population and would speak only Vietnamese during the trip. Much to TK's chagrin, BT would continuously violate that agreement. This caused TK at one point to exclaim sarcastically, "BT, speak louder, yell out that we're not from here." BT's only defense was that "I couldn't remember the words in Vietnamese." The threesome tried to pass as native Vietnamese from a different region from wherever they were traveling, but with questionable success. They had expected to be accepted as native Vietnamese. These reactions spoke to the strong desire to belong as they had once, as children. Sensitive to issues of privilege and hierarchy from their social justice youth training, they tried to deflect their Việt Kiều identities but were betrayed by their performativities (Bell, 1999).

Many first and second-generation immigrant young people, having experienced racial discrimination in the United States, often hope to feel accepted in their home country only to find that this is, more often than not, a false hope. As presented later, TK and VT were most emphatic about their contradictory feelings around belonging in their home country. Similarly, BT recounted: "The one thing that I didn't like is that they didn't think I'm Vietnamese." She had gotten a lot of attention on the street when she took her little cousin to school. I asked her what prompted the attention; she replied, "my hair and my height." At a slim 5'10' with long silver blond hair, BT turned heads. It had not occurred to her that her American way of dressing and nonverbal language would set her apart: "I expect to go back and fit in ... but, no, they knew immediately I'm not from there." This experience took her aback as she had not felt she belonged in the States, and back in Vietnam, she did not belong either:

It just really shocked me a little bit, because for the longest time, I don't feel the sense of belonging here [in the United States]. Going back, I'm not belonging there either. Where do I belong?

As Somerville (2008) pointed out, transnational identity formation may be expressed through fashion and clothing, thereby marking one as non-native. BT also realized that some of her pragmatic behavior or manners were also inappropriate. For instance, she kept saying "excuse me" 
and was deemed "too polite" by native Vietnamese speakers - a feature that Vo (2009) signals as characteristically Việt Kiều.

\section{A Việt Kiều Identity}

The Vietnamese diaspora, caused by war and the concomitant migration to developed countries, resulted in different power relations within the family. Relatives in the home country often relied on remittances to survive or to have a better quality of life, especially in terms of schooling. In addition, they could hope for a passage to the United States through family unification. Thus, there were many pressures put on Việt Kiều, who were fortunate enough to leave for Europe, Australia, or the United States. Often people in the home country tended to essentialize this identity, ascribing to those who return from abroad, especially from the United States, an easier life of financial success and educational opportunity. It seemed that Việt Kiều had a tentative right to belong but, perhaps both in the attitudes of government and relatives, largely for instrumental purposes. (Koh, 2015; Long, 2004; Small, 2019)

Although she did not articulate it this way, BT also felt that while her relatives accepted her as part of the family, they also saw her as Việt Kiều, someone with opportunities in America. This was evident when she returned for a second visit and the family kept asking about her progress in college. When she told them she was taking time off, they seemed extremely concerned. However, their reason why ("Because you can take care of [us], so then [we] can borrow money from you.") was disappointing. Not yet 21, BT felt the pressure of filial responsibility as a daughter in her nuclear family and now as Việt Kiều in her extended family.

However, being Việt Kiều did not figure as prominently for TK as he had anticipated. Perhaps because he was a recent graduate, he felt that his friends and relatives did not have the common expectations that overseas Viet from the United States would come with gifts and money. Following the usual Việt Kiều norms, his mother had instructed that he should pay for his friends and family because "it was what you should do." Nonetheless, he felt his reception as a Vietnamese American. An encounter that further pushed him to reflect on his privileged Việt Kiều and American status was meeting his younger female cousin after eight years away. Unexpectedly and disappointedly, he found that she was no longer a lively happy youngster but a young woman who saw little hope of a better future for herself. He stated,

It kind of broke my heart a little bit. A lot of stuff has happened between her parents and she had to move back to the countryside to live with her parents. And there are not a lot of opportunities for her. Had I stayed in Vietnam would I have been able to do stuff that I really want to do? Would I've been able to find my passion or whatever? So there was a lot of reflection in that way, and I feel kind of guilty for that.

Although TK and VT were well aware of their overseas status, they reflected on how their belonging was primarily from a position of privilege. VT commented on how the social futures of his cousins of approximately the same age were severely constrained by the lack of educational and economic opportunities in Vietnam. Consequently, TK and VT felt the contradictory positionality of which Anthias speaks (2009) — in other words, the contrast between their subaltern status in the United States and their privileged status in Vietnam as well-off persons with U.S. 
citizenship and opportunities for education, professional advancement, and social and economic mobility.

\section{Three Vignettes: A Desire for "Home"}

Each of the three Viet young people had different stories to tell about their so-called homecoming. Although they had some similar experiences as Việt Kiều, they had significantly different interactions with family. TK had an enthusiastic warm welcome; VT tended to avoid family interaction; and BT, anticipating a negative reaction, found love and caring with her extended family instead of her nuclear family. Each found or imagined finding some way to strengthen their tie with the home country and perhaps, be able to belong more authentically.

\section{A Welcome Home: Almost Feeling Like I Never Left}

TK had the most welcoming reception of the three returning Viet young people. I realized that TK also was reinforcing his transnational identity when he stated his desire to return to Vietnam to do research there, to contribute, and to make connections between here and there. Indeed, a stronger indication of this borderlands identity (Anzuldúa, 1987) was TK's feeling of allegiance both to Vietnam, his mother country, and, as he said, "to Philadelphia but not the United States." This related to where the concept of home was for him: "I used to think that I had to choose a home; but there's no law or rule that I have to just choose one place. I can't just lose the ties with my people there." TK's sentiments mirrored those of one of the diasporic subjects in Christou's study who also struggled with her sense of belonging: "I still get confused because something inside me wants to say that I belong here but also to there. And then I say OK I belong to myself"' (2011, p. 253). On a similar note, Ni Laoire et al. (2010) saw "home as a fluid and evolving process," which "involves a negotiation of multiple and complex attachments and detachments at different scales." This is reflected in TK's allegiance to his home city, Philadelphia, where he is a social justice activist, but not to the U.S., which he regards as an oppressive neoliberal superpower. What did unsettle TK was the new spatial order in Ho Chi Min City (HCMC) fueled by foreign investment: immense new high-rises, luxury condos, American companies, and Japanese brands. From his standpoint as a social justice activist, he remarked on what he perceived as neocolonialism:

It makes you just reflect on the system of capitalism. This is like just learning about this abstract concept. I mean seeing it manifesting here was a different thing, but coming back home, seeing it affecting the people that I really cared about and my friends and just the whole city and how it has really changed and been influenced by all this and seeing my family ... it was like more reflection on my relationship with the system and with the people.

To mark his return to and from "home," TK got a tattoo of a compass on his left arm, with the compass directions abbreviated in Vietnamese, but with the direction, south, fully spelled out. He said "south" pointed to his heart. This made sense in terms of his attachments to South Vietnam and South Philly. The tattoo was an embodied semiotic of his love and attachment to his homeland and his neighborhood.

Upon returning, TK realized how much he had missed Vietnam. He said he felt very familiar there yet at the same time somewhat strange. Thus, he was playing in his mind and feelings 
with these perceptions of sameness and difference simultaneously. Being highly proficient in Vietnamese, he was able to interact with his middle school friends and family, seemingly picking up where he left off_- "juggling between reconciling the feeling that I never left at all." Nonetheless, at the same time, he realized that both he and his peers had changed a lot. Again the issue of TK's privilege as a Việt Kiều versus the circumstances of his peers, who were so limited in their life possibilities, became a contradiction for him. His emotions ranged from excitement and joy to sadness, confusion, and ambivalence.

\section{Intergenerational Memories and Family Distance}

VT and I did not speak so much about his returning to Vietnam; we talked more about his experiences negotiating belonging in college or within his family. I felt this had to do with his premigration experience with his family. Not uncommon in Asian families, siblings were separated and lived with different extended family. VT and his older brother did not spend their entire childhood together; for extended periods, his brother lived with the grandparents. VT felt that being the eldest Asian son, his older brother developed a superiority complex as a consequence of being catered to by the grandparents. It seemed that this distance between the siblings remained, perhaps exacerbated by the fact that the older brother still seemed to occupy a privileged position and was doing little, in VT's estimation, to support his parents in Philadelphia. Moreover, VT did not feel he belonged in his family's house in Philadelphia. It was not his home because of the homophobic attitudes of his parents and brother. After high school, he seldom visited for more than two weeks and his peripatetic spirit led him to look for a spiritual "home" elsewhere and anywhere around the globe. Elements of "home" he valued and remembered from Vietnam brought him a sense of familiarity and mediated the strangeness when he traveled, especially to Paris, where he found the boulevards, apartment blocks with ground floor shops, and French loan words (e.g., croissants, café, and paté) evoked the colonial cityscape of HCMC. These "involuntary memories," defined as "sudden sharp moments when impressions of some past place or event springs fully formed into one's mind" (Game, 1991, cited in Jones, 2007, p. 209) posed the question of what meaning these convergences of past and present moments hold for us. For VT, it seemed a kind of validation of both Paris and Vietnam as places he might belong.

I asked VT about his return to Vietnam to visit relatives and to travel. As with TK and BT, he felt decidedly more American when he was in Vietnam. He went on to explain how he felt privileged as a U.S. citizen and Việt Kiều. He had stayed with his grandmother in town and visited his aunt and cousins in the countryside. He felt that unlike his cousins, he was seen to have agency and choices for the future. He sensed no envy from his cousins, but a sense of resignation of living day to day with no aspirations which had any hopes of being realized. That made him sad. He said that without education or work, young people in Vietnam turn to crime and drugs just as they do in the United States.

A few years later, VT was in HCMC working on a Fulbright project to establish an elite university in collaboration with Harvard. Hired to develop student support services, he knew his Việt Kiều status had been a key advantage in securing the position. Furthermore, his identity as an American college-educated Việt Kiều provided added cache, especially in the eyes of well-to-do parents, who wished to enroll their children.

Since he had been back for almost a year, I asked him whether he had seen any of his relatives. He said he was avoiding going to the Mekong Delta, a long and arduous trip by bus. However, I sensed that there were some residual intergenerational family tensions that elicited 
some anxiety for VT. These included the memories of the grandparents' deferential treatment of his elder brother and also their treatment of his mother, who had been adopted and treated as a household servant. When he did fulfill a filial duty as grandson and nephew by eventually visiting before returning to the United States, he was saddened by the demise of his grandfather, who had suffered two strokes and was now confined to a wheel chair, and the strain on the family to provide his care. Seeing the sharp contrast with his privileges in the United States, VT was uncomfortable arriving again with his privileged status as Việt Kiều. Looking toward the future, VT desired a further connection to Vietnam, desiring to return to HCMC and open a salon or café where expats could engage in intellectual and political discourse. In his transnational imagination, given the politics of belonging, he could use his Việt Kiều status to advantage and make a place for himself to belong.

\section{Finding Family and "Home" Abroad}

When BT first returned to HCMC, it was an academic and family crisis situation that propelled BT to use all her savings to go to HCMC for a physical and emotional respite. Initially, she figured she would only spend a few days with her family. One reason being that given her parents' divorce and father's remarriage, she felt that perhaps she would not be much welcomed by that side of the family.

Cross-cultural miscommunication seemed to affect BT's expectations and those of her extended family. There were two heart-rending examples that BT recounted. The first week there, BT had little appetite for food. Concerned about her diet, her aunt had offered to cook something that she liked and asked BT if she would be back for dinner. Although she had plans to be with friends, BT replied that she would return in order not to disappoint her aunt. However, BT stayed out late and, upon returning, saw that food was still laid out on the table. When she asked about this the next morning, her aunt replied that they had waited for her for dinner. Feeling quite ashamed, BT apologized and started to describe her home life, explaining that she was not used to a "family lifestyle." In fact, she usually ate alone and no one ever waited for her. This was the first glimpse that her extended family had of her chaotic family life in the United States. Her aunt's annoyance turned to compassion. Understanding that BT's path had not been easy despite living in the U.S., her grandmother and aunt tried to be understanding and encouraging: "Get a job. Don't worry about your family anymore, just don't bother with them anymore." In this incident BT totally misconstrued her extended family's expectations of filial respect, the result of which led her to dispel some stereotypical beliefs about the quality of life of Việt Kiều relatives in the United States.

Following the dinner incident, at different times her grandmother, aunt, or older cousin would give her a gift of a hundred U.S. dollars. Feeling guilty accepting these gifts, given how difficult it was for family members to save up this money, she objected : "No, please! I make that much in a day." She recalled herself saying, "I don't struggle that bad;" and her aunt saying, "No, no, no, I save this for you." BT recalled: "It made me feel so bad ... They make dimes and pennies and they saved that for me." Despite her protests, the family members pressed the gifts on her, saying that these were "homecoming gifts." For the first time in a long time BT felt she had family who cared about her and a place where she belonged. Upon departing at the airport, BT recalled: "I just broke down crying." Ironically, BT had experienced an inversion of her status as Việt Kiều. Instead of gifting her relatives, she had been the recipient of their largesse, empathy, and caring. 
Subsequent to BT's visit to her grandmother and aunt Vietnam, she met her grandmother in Germany, where she again became acquainted with a younger paternal uncle whose family she has visited several times over the years. So, for BT, her sense of belonging was complicated by not belonging in her nuclear family in the United States and feeling that she belonged more with her grandmother and aunt despite the logistics and differences in standard of living. Her journey "home" led to "homes" elsewhere, none in the city where she and her teenage brother lived - her parents having left. As Ni Laoire et al. (2010) assert, "home is not only or necessarily associated with a place moved to or from, but involves a negotiation of multiple and complex attachments and detachments at different scales (p. 160). This was evident in BT's life.

\section{Discussion: Between Borders}

Visiting the home country for the first time since emigrating was a situation of not really belonging and existing in the liminal borderland. All three Vietnamese American young people experienced the "ambivalence of transnational belonging" (Christou, 2011, p. 250) neither fully here nor there. In the words of one ex-patriot, they found themselves feeling, "too American for Vietnamese people and too Vietnamese for Americans" (Hobson, n.d.). They were awakened by their migration experience to the fact that they no longer belonged entirely anywhere due to their social locations, identities, and ways they were viewed and assessed (Yuval-Davis, 2006). BT seemed most discombobulated by this experience; she had not been reflexive enough to realize that her physical appearance and her translanguaging made her standout as non-native. VT and TK expressed their social distance from their cousins in terms of the opportunities they had to design their own social futures. For the three Vietnamese American young people, there was a mix of emotions from some shock or disappointment of no longer "fitting in" to feelings of privilege, good fortune, and perhaps a little guilt from being "American." TK, aided by his highly proficient bilingual skills, felt more "at home" in Vietnam but felt allegiance to his social justice work in the United States, leading him to wonder for himself "Where is home?" and "What is home?" were for him-thus echoing the sentiments of so many migrants. VT nurtured a distant desire to return to Vietnam as a talented professional using his English proficiency and college education to advantage in becoming an expat. Here belonging was mitigated by varying degrees of emotional attachment to Vietnam (Yuval-Davis, 2006, p. 199).

The varied responses of the young people to issues about belonging in Vietnam involved evocation of memories, reflections, emotions, and emotional labor rather than descriptions of places. Significantly, their recounting of their homecomings engendered epiphanies about their own emotional landscape and social locations both in the United States and in Vietnam. Their feelings for their home country cannot be separated from their sense of belonging in the United States and whether they feel they have a home here. On one hand,

Home for immigrants is both a concept and a desire - for a better life, for safety, for family unity, for community - even though these desires are often made unrealizable by immigration laws and the national(ist) boundaries they (re)produce. Yet, home for immigrants can also be an act of resistance. (Espiritu, 2003, p. 128 cited in Ribero, p. 275).

On the other hand, home is also conceptualized as a place where 
Creating the nation-as-home in which the immigrant family can be safeguarded is itself a form of refusal of neoliberal economic policies and practices that depend on the displacement and immigration of low-skilled, low-wage laborers. Prioritizing family unity can counter the prioritization of labor and capital. (Ribero, 2018, pp. 275-276)

For social justice activists like TK, BT, and VT, their fight to belong in the United States aligns with this latter quote. At the same time their transnational identities, memories, and family ties draw them back continually to Vietnam. What could translocational belonging mean in everyday life for them? What would be the psychic and material affordances or costs of maintaining lives in both countries? Already in the lives of these three, the notion of "home" was already a fluid notion, not moored to tradition or a geographical place.

As Zuniga and Hamann point out, "Migration is inherently a break, a form of dispersion, and a disjuncture" (2015, p. 645). What we are trying to understand in examining notions and experiences of "home" and belonging is how children make sense of their "disruptive geographies" (Ibid). I believe exploring these "disruptive" geographies of young people might figure importantly in understanding issues of self-care, socio-emotional well-being, and intergenerational transmission of trauma (Gonzales, Suárez-Orozco, \& Dedios-Sanguineti, 2013; Phipps \& DeggesWhite, 2014). Although the experiences of these journeys seem to lie parallel to their everyday work or school lives, I feel further research may reveal how we might understand how these emotional palimpsests represent hidden currents influencing the identities and emotional lives of young immigrants.

\section{References}

Anthias, F. (2009). Translocational belonging, identity and generation: Questions and problems in migration and ethnic studies. Finnish Journal of Ethnicity and Migration, 4(1), 6-15.

Anthias, Fl. (2006). Belongings in a globalizing and unequal world: Rethinking translocations. In N. Yuval-Davis, K. Kannabiran and U. Vieten (Eds.), The situated politics of belonging (pp. 17-31). Sage.

Anzaldúa, G. (1987). Borderlands: la frontera. Aunt Lute.

Arnett, J. J. (2015). Emerging adulthood: The winding road from the late teens through the twenties ( $2^{\text {nd }}$ edition). Oxford University Press.

Bao, Moi. (November 5 $5^{\text {th }}$ 2010). Vietnam to provide more support to Việt Kiều. http://en.baomoi.com/Info/Vietnam-to-provide-more-support-to-Việt Kiều /3/79864.epi. Accessed November 20, 2010.

Bell, V. (1999). Performativity and belonging: An introduction. Theory, Culture \& Society, 16(2), pp. 1-10.

Bondi, L. (2005). Making connections and thinking through emotions: Between geography and psychotherapy. Transactions of the Institute of British Geographers, 30, 433-448.

Christou, A. (2011). Narrating lives in (e)motion: Embodiment, belongingness and displacement in diasporic spaces of home and return. Emotion, Space and Society, 4, 49-257.

Espiritu, Y. L. (2003). Home bound: Filipino American lives across cultures, communities, and countries. University of California Press. 
Fortier, A. (2000). Migrant belongings: Memory, space, identities. Berg Publishers.

Gonzales, R. G., Suárez-Orozco, C., \& Dedios-Sanguineti, M. C. (2013). No place to belong: Contextualizing concepts of mental health among undocumented immigrant youth in the United States. American Behavioral Scientist, 57(8), 1174-1199.

Hobson, J.K. (n.d.). Identity: American Việt Kiều millennials. City Pass Guide. https://www.citypassguide.com/travel/vietnam/practicalities/blog/american-viet-kieuidentities-shift-through-repatriation-in-vietnam Accessed 2.29.20

Jones, O. (2005). An emotional ecology of memory, self and landscape. In J. Davidson, L. Bondi, \& M. Smith (Eds.) Emotional geographies (pp. 205-218). Ashgate.

Koh, P. (2015). You can come home again: Narratives of home and belonging among secondgeneration Việt Kiều in Vietnam. Sojourn: Journal of Social Issues in Southeast Asia, 30(1), 173-214.

Long, L. D. (2004). Việt Kiều on a fast track back? In L. D. Long, \& E. Oxfeld (Eds.), Coming home? Refugees, migrants, and those who stayed behind (pp. 65-89). University of Pennsylvania Press.

Nunn, C. (2017). Negotiating national (non)belongings: Vietnamese Australians in ethno/multicultural Australia, Identities, 24(2), 216-235.

Ní Laoire, C., Carpena-Méndez, F., Tyrrell, N., \& White, A. (2010). Introduction: Childhood and migration - mobilities, homes and belongings. Childhood, 17(2), 155-162.

Phipps, R. M., \& Degges-White, S. (2014). A new look at transgenerational trauma transmission: Second-generation Latino immigrant youth. Journal of Multicultural Counseling and Development, 42(3), 174-187.

Probyn, E. (1996). Outside Belongings. Routledge.

Ribero, A. M. (2018). "Papá, Mamá, I'm coming home": Family, home, and the neoliberal immigrant nation in the national immigrant youth alliance's "bring them home" campaign. Rhetoric Review, 37(3), 273-285.

Skrbis, A. (2008). Transnational families: Theorizing migration, emotions and belonging. Journal of Intercultural Studies, 29(3), 231-248.

Small, I. V. (2019). How Vietnamese-Americans and other "Việt Kiều" fuel capitalist dreams with remittances. This Week in Asia. https://www.scmp.com/week-asia/opinion/article/3020310/how-vietnamese-americansand-other-viet-kieu-fuel-capitalist._Accessed 2.29.20.

Somerville, K. (2008). Transnational belonging among second-generation youth: Identity in a globalized world. Journal of Social Sciences, 10(1), 23-33.

Suárez-Orozco, M., Suárez-Orozco, C., \& Todorova, I. (2008). Learning a new land. Harvard University Press.

Thai. Hung C. (1999). "Splitting things in half is so white!": Conceptions of family life and friendship and the formation of ethnic identity among second generation Vietnamese Americans. Amerasia Journal, 25(1), 53-88.

Vo, N.M. (Ed.). (2009). The Việt Kiều in America: Personal accounts of postwar immigrants from Vietnam. McFarland \& Co. Inc.

Yee, M. (2016). We have the power to make change": The struggle of Asian immigrant youth against school violence." In J. O. Conner \& S. Rosen (Eds.), Contemporary Youth Activism: Advancing social justice in the United States (pp. 289-310). American Bibliographical Center (ABC)-CLIO. 
Yuval-Davis, N. (2006). Belonging and the politics of belonging. Patterns of Prejudice, 40(3), 197-214.

Zúñiga, V., \& Hamann, E. T. (2015). Going to a home you have never been to: The return migration of Mexican and American-Mexican children. Children's Geographies, 13(6), 643-655.

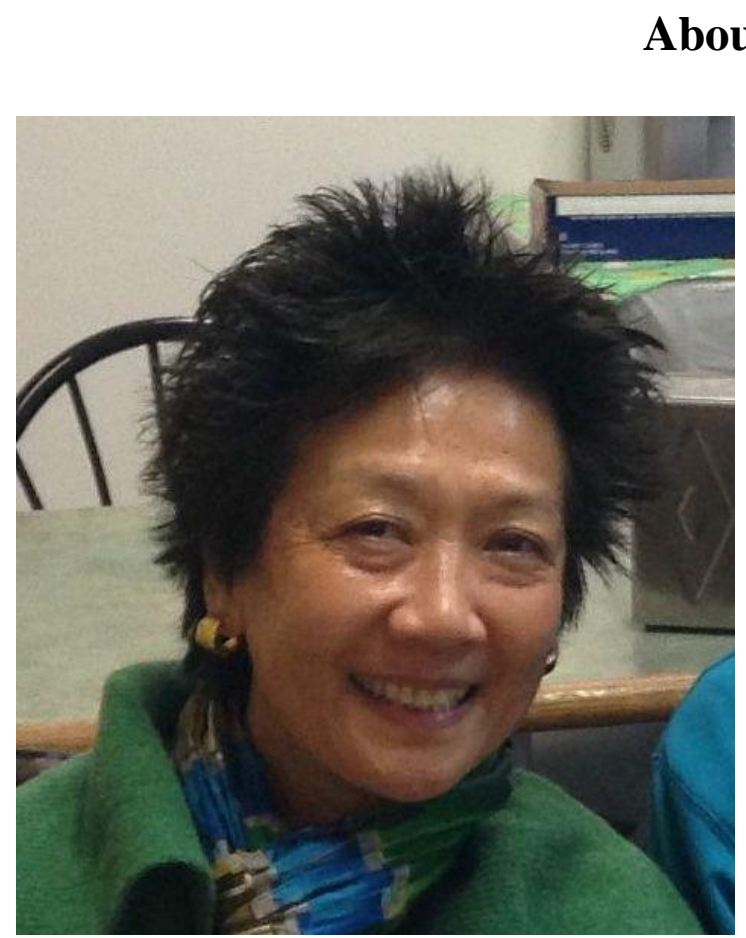

Mary Yee, born in Rutland, Vermont, grew up in Boston Chinatown, the child of a working-class immigrant family. For over 35 years, Dr. Yee has worked extensively with immigrant and refugee communities. She was a founder of Asian Americans United (AAU) and Yellow Seeds, Asian American organizing and advocacy organizations in Philadelphia. She was deeply involved in challenging urban renewal projects encroaching on Chinatown, most notably the Vine Street Expressway, the Phillies baseball stadium, and the Foxwoods Casino. In her professional educational career as a central office administrator at the School District of Philadelphia, Dr. Yee worked in the areas of ESOL and bilingual education, compliance monitoring, family engagement and language access. Dr. Yee holds degrees from Princeton University in East Asian Studies and the University of Pennsylvania in City Planning and TESOL. She completed her doctoral degree in literacy studies at the University of Pennsylvania Graduate School of Education. Her dissertation research focused on first generation Asian immigrant youth activists. Her other research interests include educational issues in immigrant communities, community organizing, university-community partnerships, psycho-social healing, and the interrelationship between health and educational disparities. 

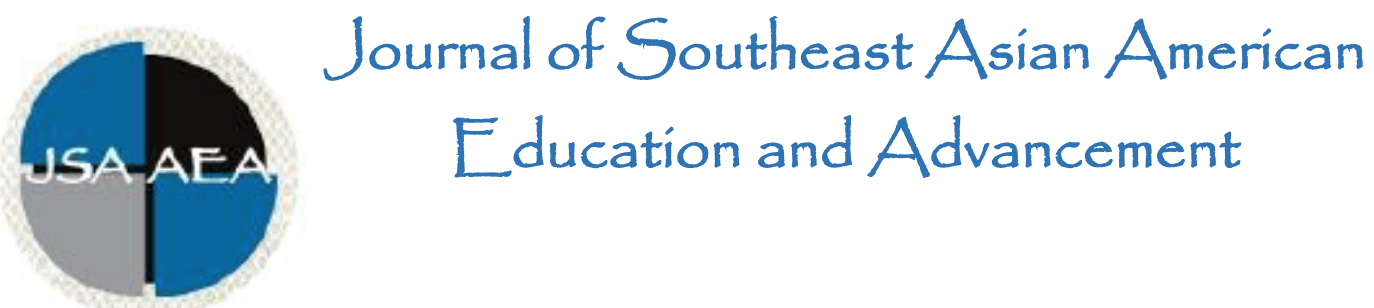

Vol. 15 Iss. 2 Special Issue (2020) $\quad$ www.JSAAEA.org

Special Issue Co-Editors

Dr. Peter T. Keo

Stanford University

Dr. Loan Thi Dao

St. Mary's College of California

Editor

Dr. Wayne E. Wright

Purdue University

Associate Editors

Dr. Chhany Sak-Humphry

University of Hawaii at Manoa

Dr. Phitsamay Sychitkokhong Uy

University of Massachusetts, Lowell

\author{
Book Review Editor \\ Dr. Vichet Chhuon \\ University of Minnesota \\ Creative Works Editor \\ Bryan Thao Worra \\ Lao Assistance Center \\ Journal Manager \\ Fang Gao \\ Purdue University
}

\title{
Editorial Review Board
}

Dr. Steve Arounsack

California State University, Stanislaus

Dr. Sovicheth Boun

Salem State University
Dr. Carl L. Bankston III

Tulane University

Dr. Phala Chea

Lowell Public Schools 


\author{
Dr. Virak Chan \\ Purdue University \\ Dr. Loan Dao \\ St. Mary's College of California \\ Dr. Changming Duan \\ University of Missouri-Kansas City \\ Dr. Sothy Eng \\ Lehigh University \\ Dr. Vincent K. Her \\ University of Wisconsin, Eau Claire \\ Dr. Peter Nien-Chu Kiang \\ University of Massachusetts, Boston \\ Dr. Kevin K. Kumashiro \\ University of Illinois, Chicago \\ Dr. Ha Lam \\ Independent Scholar \\ Dr. Jonathan H. X. Lee \\ San Francisco State University \\ Dr. Monirith Ly \\ Royal University of Phnom Penh \\ Dr. Bic Ngo \\ University of Minnesota \\ Dr. Leakhena Nou \\ California State University, Long Beach \\ Dr. Mark Pfeifer \\ SUNY Institute of Technology \\ Dr. Loan T. Phan \\ University of New Hampshire \\ Dr. Karen Quintiliani \\ California State University, Long Beach \\ Dr. Angela Reyes \\ Hunter College \\ The City University of New York \\ Dr. Fay Shin \\ California State University, Long Beach \\ Dr. Christine Su \\ College of San Mateo \\ Dr. Alisia Tran \\ Arizona State University \\ Dr. Khatharya Um \\ University of California, Berkeley \\ Dr. Kim Tran \\ University of California, Los Angeles, \\ Glendale Community College \\ Dr. Molly Wiebie \\ The University of Texas at Austin
}

Dr. George Chigas

University of Massachusetts, Lowell

Dr. Hien Duc Do

San Jose State University

Dr. Sophal Ear

Occidental College

Dr. Jeremy Hein

University of Wisconsin, Eau Claire

Dr. Nancy H. Hornberger

University of Pennsylvania

Dr. Peter Tan Keo

Stanford University

Dr. Yvonne Kwan

San Jose State University

Dr. Ravy Lao

California State University, Los Angeles

Dr. Stacey Lee

University of Wisconsin, Madison

Dr. Sue Needham

California State University, Dominguez Hills

Dr. Max Niedzwiecki

Daylight Consulting Group

Dr. Clara Park

California State University, Northridge

Dr. Giang Pham

University of Massachusetts Amherst

Dr. Malaphone Phommasa

University of Clifornia Santa Barbara

Dr. Kalyani Rai

University of Wisconsin-Milwaukee

Dr. Cathy J. Schlund-Vials

University of Connecticut, Storrs

Dr. Nancy J. Smith-Hefner

Boston University

Dr. Yer J. Thao

Portland State University

Dr. Monica M. Trieu

Purdue University

Dr. Silvy Un

Saint Paul Public Schools

Dr. Linda Trinh Vo

University of California, Irvine

Dr. Yang Sao Xiong

The University of Wisconsin-Madison

Dr. Zha Blong Xiong

University of Minnesota 


\section{Doctoral Student Editorial Review Board}

\author{
Diana Chandara \\ University of Minnesota-TwinCiteis \\ Linh Dang \\ University of Rochester \\ Annie BichLoan Duong \\ San Joaquin County Office of Education \\ Jacqueline Mac \\ Indiana University \\ Vanessa Sovanika Na \\ University of California SanDiego \\ Khoi Nguyen \\ George Mason University \\ Linda Marie Pheng \\ University of Wisconsin-Madison \\ Latana Thaviseth \\ University of California Los Angeles \\ Melissa Vang \\ San Diego State University \\ Soua Xiong \\ San Diego State University \\ Claremont Graduate University
}

\author{
Kassandra Chhay \\ University of Minnesota-Twin Cities \\ Bao Diep \\ University of Minnesota-Twin Cities \\ Nielson Hul \\ Cornell University \\ Dung Minh Mao \\ University of Minnesota-Twin Cities \\ Hoa Nha Nguyen \\ Boston College \\ Thien-Huong Ninh \\ University of Southern California \\ Krissyvan Truong \\ Claremont Graduate University \\ Mai Vang \\ University of Massachusetts Boston \\ Thong Vang \\ University of Minnesota-Twin Cities
}

